\title{
UDC 541.135 \\ COMPARATIVE STUDY OF Pt-BASED CATALYSTS SUPPORTED ON VARIOUS CARBON SUPPORTS FOR SOLID POLYMER ELECTROLYTE ELECTROCHEMICAL SYSTEMS
}

\author{
I.E. Baranov ${ }^{1}$, V.I. Porembskii ${ }^{1}$, E.K. Lyutikova ${ }^{1}$, I.I. Nikolaev ${ }^{1}$, V.V. Markelov ${ }^{1}$, O.K. \\ Alekseeva $^{1}$, S.V. Ostrovskii ${ }^{1}$, A.A. Kalinnikov ${ }^{1}$, S.V. Akelkina ${ }^{1}$, A.S. Pushkarev ${ }^{1,2}$, \\ M.A. Solovyev ${ }^{1,2}$, I.V. Pushkareva ${ }^{1,2}$, V.N. Fateev ${ }^{1}$ \\ ${ }^{I}$ National Research Center «Kurchatov Institute» \\ 1, Akademika Kurchatova sq., Moscow, 123182, Russia, e-mail: fateev_vn@nrcki.ru \\ ${ }^{2}$ National Research University «Moscow Power Engineering Institute» \\ 14, Krasnokazarmennaya st., Moscow, 111250, Russia
}

Received 02.09.2019

\begin{abstract}
The comparative study of electrocatalysts synthesized by chemical reduction and pulsed magnetron-ion sputtering for polymer electrolyte membrane electrochemical systems are presented. Various carbon nanomaterials were used as supports of Pt nanoparticles: carbon black, nanotubes, nanofibers and reduced graphene oxide. The electrochemical studies of the obtained electrocatalysts as well as their testing in the fuel cell membrane-electrode assembly were carried out. The influence of supports morphology and the deposition approach of Pt nanoparticles on the electrochemically active surface area and activity of electrocatalysts, as well as the prospects of the magnetron-ion sputtering approach for electrocatalysts synthesis were studied and discussed.

Keywords: supported catalyst, reduce graphene oxide, carbon nanofibers, magnetron ion sputtering, PEM fuel cell
\end{abstract}

DOI: $10.32737 / 2221-8688-2019-4-489-499$

\section{Introduction}

An efficiency and a performance of polymer electrolyte membrane (PEM) electrochemical systems (fuel cells (FC) [1], oxygen concentrator [2], electrolysis cell for ozone production [3], reversible fuel cells [45] etc.) considerably depend on the structure and properties of the both the catalyst and the catalytic layer based on it. Carbon supported nanosized Pt particles are usually used as electrocatalyst for these devises. Therewith, the catalyst performance during its operation as a part of the cathode catalytic layer is determined by both the electrochemically active surface area (EASA) of the nanosized $\mathrm{Pt}$ particles and the capability of the reagent access to these particles, which in turn is governed by the structure of carbon support particles and the catalytic layer structure. In order to provide uniform distribution of the catalyst over the layer volume and to assist the reagent access to active electrocatalyst particles, the typical size of carbon support particles should not significantly exceed the $\mathrm{Pt}$ particles size (3-5 $\mathrm{nm} \mathrm{[6]).} \mathrm{Therefore,} \mathrm{the}$

search for new nanosized carbon supports and methods of the Pt deposition, which allow to obtain the optimal structure of both the support and Pt nanoparticles from the point of view of catalyst activity and stability is necessary [7$11]$.

Pt deposited on a pretreated carbon black (for example, Vulcan XC-72R) by chemical reduction [11-12] is one of the common types of the catalyst for FC. The disadvantages of chemical synthesis methods, such as high-power consumption and multiple stages (high duration and complexity) of the process, aggregation of nanoparticles, losses during washing of the electrocatalyst, make us look for alternative approaches for the synthesis of electrocatalysts. One of these methods is the magnetron-ion sputtering (MIS) [7], which is free from the most of the above discussed disadvantages.

The aim of this work is to study alternative carbon support materials for electrocatalytically active Pt particles and new method of nanosized Pt particles deposition on 
these supports for FC. Pt catalysts supported on different nanostructured carbon materials synthesized by various methods were investigated. The structure of the synthesized catalysts was studied by transmission electron microscopy (TEM). The electrochemical properties of the obtained catalysts were studied by cyclic voltammetry and quasistationary polarization curves at low potential scan rate [8] in a three-electrode glass cell, as well as in the polymer electrolyte membrane fuel cell.

\subsection{Used nanostructured materials}

In the present work the following carbon support materials were investigated: nitrogen-doped multi-walled carbon nanotubes (MWCNTs) (5 at.\% N-MWCNTs), which were synthesized by decomposition of the $40 \% \mathrm{C}_{2} \mathrm{H}_{4} / 60 \% \mathrm{NH}_{3}$ mixture using the $\mathrm{Fe}$ containing catalyst at $700{ }^{\circ} \mathrm{C}$ [13]. Carbon nanofibers (CNF) provided by Grupo Graphenano (Spain) [14], Vulcan XC-72R carbon black (Cabot, USA) (the commonly used carbon support of PEMFC electrocatalysts) and reduced graphene oxide (RGO) [1, 15-16].

\subsection{Synthesis of the catalysts supported on various carbon materials}

Nanosized Pt particles were deposited on the carbon support by the chemical reduction approach ("polyol", ethylene glycol reduction) [8] or MIS approach [7, 17]. These methods provide the deposition of $\mathrm{Pt}$

\section{Experimental}

nanoparticles with the face-centered cubic lattice with the (111) plan prevailing confirmed by X-ray diffraction [18-19]. Our data for catalysts studied in presented work obtained using Röntgen (PW3040/60 X'Pert Pro) diffractometer are in a good agreement with the mentioned ones.

The magnetron sputtering system consisting of the DC laboratory installation (MIR-1), the bipolar power source APELSB5BP-1300 and a device for powder mixing during deposition process was used for the electrocatalytic layer deposition by MIS [18]. The parameters of the Pt pulse deposition onto different carbon supports are described in detail in refs. [17, 20].

Investigated catalysts synthesized by various approaches and their electrochemically active surface area (EASA) which were investigated by cyclic voltammetry are listed in Table 1.

Table 1. The list of studied catalysts

\begin{tabular}{|c|c|c|c|c|}
\hline № & Catalyst & $\begin{array}{c}\text { Mass content of } \\
\mathrm{Pt}, \mathrm{wt} . \%\end{array}$ & Method of Pt deposition & EASA, $\mathrm{m}^{2} \mathrm{~g}^{-1} \mathrm{Pt}$ \\
\hline 1 & $\mathrm{Pt}^{40} / \mathrm{MWCNTs}$ & 39.4 & Chemical reduction & 43 \\
\hline 2 & $\mathrm{Pt}^{40} / \mathrm{RGO}$ & 40.1 & Chemical reduction & 55 \\
\hline 3 & $\mathrm{Pt}^{40} /$ Vulcan XC-72R & 39.7 & Chemical reduction & 49 \\
\hline 4 & $\mathrm{Pt}^{20} / \mathrm{CNF}$ & 20.2 & Chemical reduction & 76.6 \\
\hline 5 & $\mathrm{Pt}^{20} /$ Vulcan XC-72R & 19.8 & Chemical reduction & 71.3 \\
\hline 6 & $\mathrm{Pt}^{20} / \mathrm{CNF}$ (MIS) & 20.5 & MIS & 43.3 \\
\hline
\end{tabular}

2.3. Morphology and specific surface area studies

Specific surface area of carbon supports was measured by BET method using a porosimeter TRISTAR 3000 (Micromeritics, USA). Transmission electron microscopy (TEM) studies were done with $\operatorname{Titan}^{\text {TM }} 80-300$ S/TEM (FEI, USA) (80-300 kV, 0.07-0.08 nm space resolution). Samples was prepared through ultrasonication of catalysts in ethanol for $10 \mathrm{~min}$. and the following deposition on perforated Lacey copper mesh covered with thin X-ray amorphous carbon layer.

\subsection{Electrochemical studies}

The electrochemical characteristics of the electrocatalytic layers based on the synthesized catalysts were studied by voltammetry at various potential scan rates in $1 \mathrm{M} \mathrm{H}_{2} \mathrm{SO}_{4}$ solution using conventional threeelectrode cell at $25{ }^{\circ} \mathrm{C}$ [8]. The scan rate for 
cyclic voltammetry and "quasi-stationary" polarization curves were 20 and $0.1 \mathrm{mV} / \mathrm{s}$, respectively.

\subsection{PEMFC testing of electrocatalysts}

PEMFC membrane-electrode assembly (MEA) based on the obtained catalysts were fabricated using a Nafion 112 membrane (DuPont, USA) and Sigraset 10BB carbon paper (SGL CARBON GmbH, Germany) sheets, which were used as gas diffusion layers. The electrocatalytic layers were deposited on a microporous sublayer by air
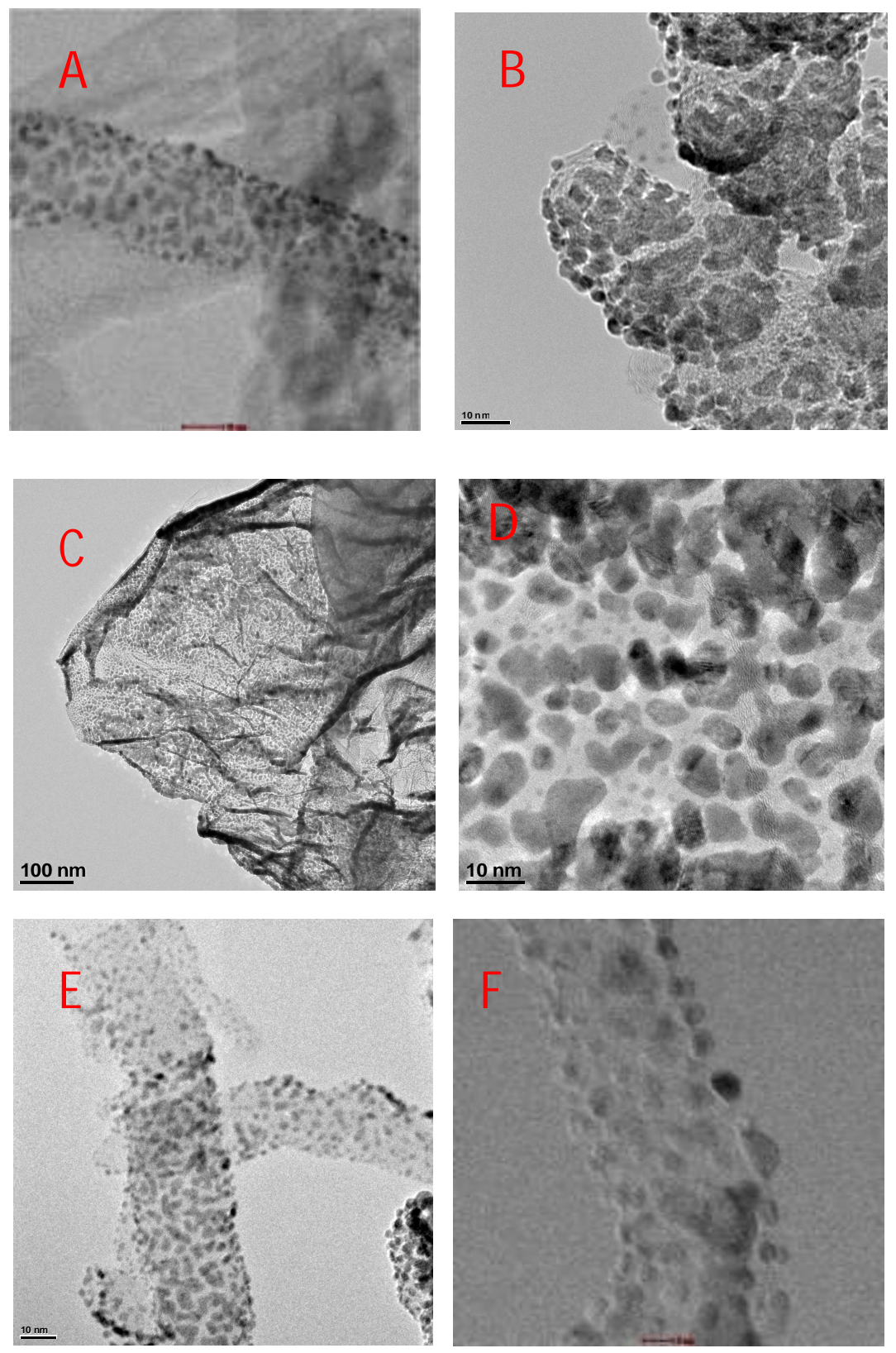
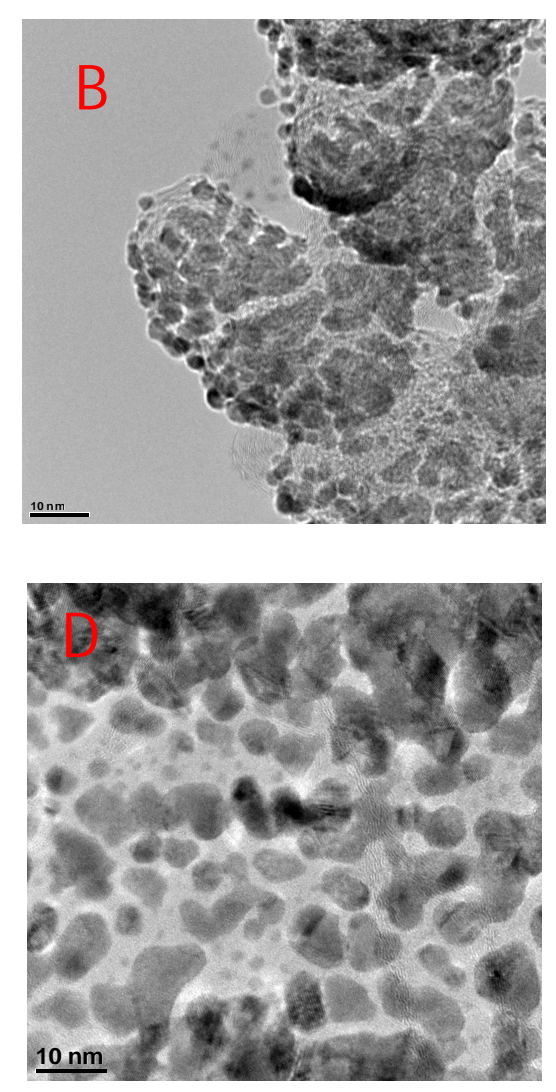

spraying of a catalyst ink. The catalyst ink in isopropyl alcohol with the addition of Nafion ionomer was prepared according to the procedure described in detail in ref. [16]. The 7 $\mathrm{cm}^{2}$-sized MEA is sandwiched between two flat titanium endplates. Titanium meshes was used as the clamping elements of the test cell monopolar plates [21]. MEA were tested using hydrogen and oxygen fed at the relative humidity of $100 \%$ at the pressure of 1 bar. The cell temperature during the test was $60{ }^{\circ} \mathrm{C}$.

Fig. 1. TEM images of $\mathrm{Pt}^{40} / \mathrm{MWCNTs}(\mathrm{A}), \mathrm{Pt}^{40} /$ Vulcan $\mathrm{XC}-72(\mathrm{~B}), \mathrm{Pt}^{40} / \mathrm{RGO}(\mathrm{C}, \mathrm{D}), \mathrm{Pt}^{20} / \mathrm{CNF}$ (E) and $\mathrm{Pt}^{20} / \mathrm{CNF}$ (MIS) (F). 


\section{RESULTS AND DISCUSSION}

3.1. Morphology studies of supports and synthesized catalysts

Morphology of synthesized catalysts was studied by TEM with high resolution. According to [13] N-MWCNTs have a bamboo-like structure with nitrogen in pyridine, pyrrole, graphite and oxidized states (according to X-ray Photoelectron Spectroscopy (XPS)). XPS spectrums of NMWCNTs revealed that nitrogen is primary in pyridine and graphite states (55-57 \%) and some molecular nitrogen is incapsulated inside the nanotubes.

TEM images of catalysts synthesized by chemical reduction supported on MWCNTs (A), Vulcan XC-72R (B), RGO (C, D) and CNF (E) as well as the CNF supported catalyst prepared by MIS method (F) are shown in Fig. 1.

Fig. 1 shows that the structure of the RGO is "crumpled" multilayer sheets. Herewith, the Pt particles are well defined, and their structure is quite similar for catalysts obtained by both synthesis approaches. The average size of Pt particles is ca. $4.5 \mathrm{~nm}$ for all electrocatalysts with $40 \mathrm{wt} . \% \mathrm{Pt}$ and ca. $3 \mathrm{~nm}$ for electrocatalysts with $20 \mathrm{wt} . \%$ Pt. These results are in a good agreement with the EASA values obtained by cyclic voltammetry (Table 1). In addition, the electrocatalysts morphology shown in fig. 1 suggests that all considered support materials have quite similar characteristic dimension of primary particles (directly on the surface of which $\mathrm{Pt}$ particles are located). Carbon black particles have a sphere shape with the diameter of up to $0.1 \mu \mathrm{m}, \mathrm{CNF}$ size is ca. $0.05-0.1 \mu \mathrm{m}$ and the "crumpled" multilayer sheet (flake) of RGO has a typical thickness of ca. $0.05 \mu \mathrm{m}$ and length of a few $\mu \mathrm{m}$, which can be explained by RGO sheets agglomeration due to Van-derWaals interaction [22].

Specific surface area of Vulcan XC72R, CNF, MWCNTs and RGO measured by BET is ca. $220-230,130-150,175-186$ and $260-280 \mathrm{~m}^{2} / \mathrm{g}$, respectively. Support particles in electrochemical systems (electrolysis and fuel cells) form large agglomerates, and $\mathrm{Pt}$ particles mainly located on the agglomerates surface participate in electrochemical reactions. The EASA values of active $\mathrm{Pt}$ particles deposited on RGO and carbon black are quite similar (Table 1) despite the significantly larger RGO specific surface area. It can be assumed that mainly Pt nanoparticles located on the RGO flake outer surface participate in electrochemical reactions. Thus, the size of the RGO flake of ca. 100-200 nm should be taken as the characteristic dimension of a such RGO agglomerate [16, 23].

\subsection{Electrochemical studies}

The results of cyclic voltammetry (CV) studies of electrocatalysts based on various supports (MWCNTs, Vulcan XC-72R and RGO) synthesized by chemical reduction are shown in Fig. 2.

The cyclic voltammetry curves of the electrocatalysts qualitatively coincide, showing clear hydrogen adsorption/desorption peaks in the potential range from -0.17 to 0.2 V (vs. SSCE (sat.)), using which EASA of electrocatalysts was calculated (Table 1). Some difference in a CV curves shape could be attributed to the difference in Pt particles surface structure (different Pt crystal faces distribution) [18]. At potentials of $0.2-0.6 \mathrm{~V}$ (rel. SSCE (sat.)) the RGO-supported catalyst demonstrates higher current density, i.e. the RGO support provides a higher double layer capacity, which is due to a defective multilayer flake structure of RGO and includes the contribution of the "inner" layers. Larger double layer capacitance could also be explained by larger amount of oxygencontaining functional groups [24], a significant part of which was not reduce during the synthesis and can serve as additional $\mathrm{Pt}$ nanoparticles nucleation sites during the synthesis. The latter also could explain more uniform distribution of Pt nanoparticles over the RGO surface and higher $\mathrm{Pt}^{40} / \mathrm{RGO}$ EASA. 


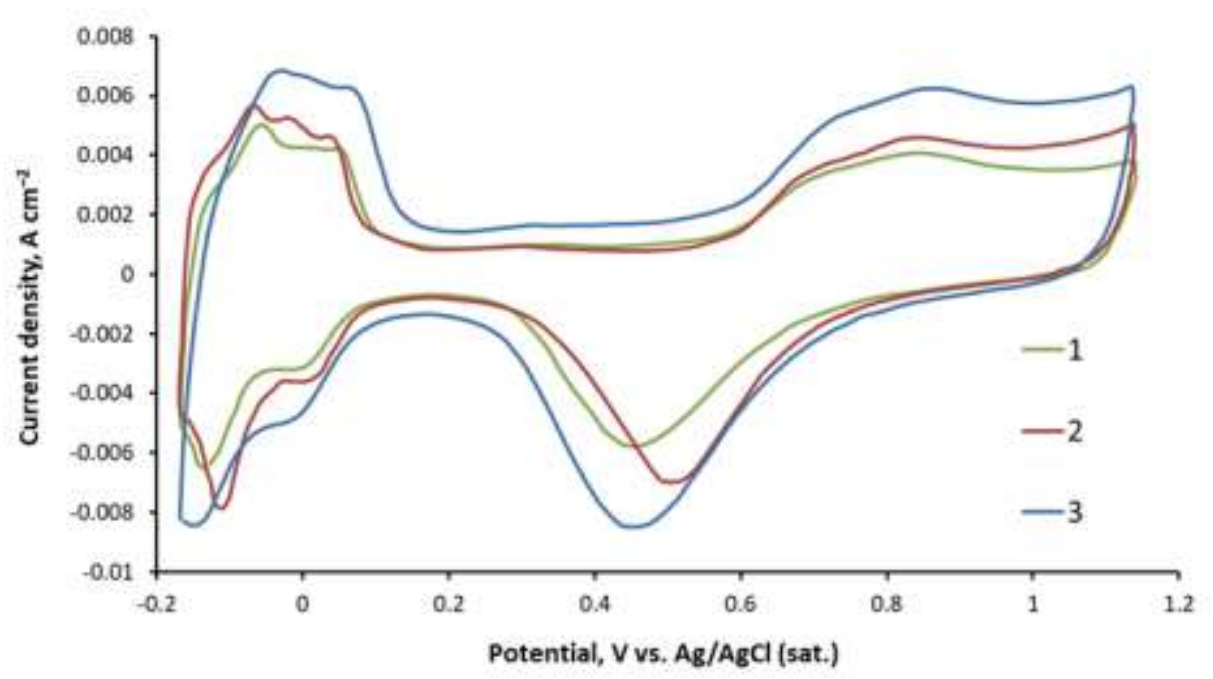

Fig. 2. Cyclic voltammetry curves of (1) $\mathrm{Pt}^{40} / \mathrm{MWCNTs}$, (2) $\mathrm{Pt}^{40} /$ Vulcan XC-72R and (3) $\mathrm{Pt}^{40} / \mathrm{RGO}$.

Carbon nanotubes are often contributes to a better dispersion and lower characterized by the lack of active sites for size of Pt nanoparticles [20].

The CV curves of electrocatalysts catalytic nanoparticles, which leads to insufficient dispersion of $\mathrm{Pt}$ particles and their agglomeration during synthesis [25]. The $\mathrm{Pt}^{40}$ /MWCNTs EASA is ca. $43 \mathrm{~m}^{2} \mathrm{~g}^{-1} \mathrm{Pt}$, slightly lower than the one of $\mathrm{Pt}^{40} /$ Vulcan XC$72 \mathrm{R}\left(49 \mathrm{~m}^{2} \mathrm{~g}^{-1} \mathrm{Pt}\right)$, which is assumed to be associated with nitrogen atoms, which synthesized by chemical reduction and MIS are shown in Fig. 3. EASA of electrocatalysts synthesized by chemical reduction on Vulcan $\mathrm{XC}-72 \mathrm{R}$ and CNF supports are almost the same, but EASA of samples synthesized by the MIS method is $1.65-1.75$ times lower.

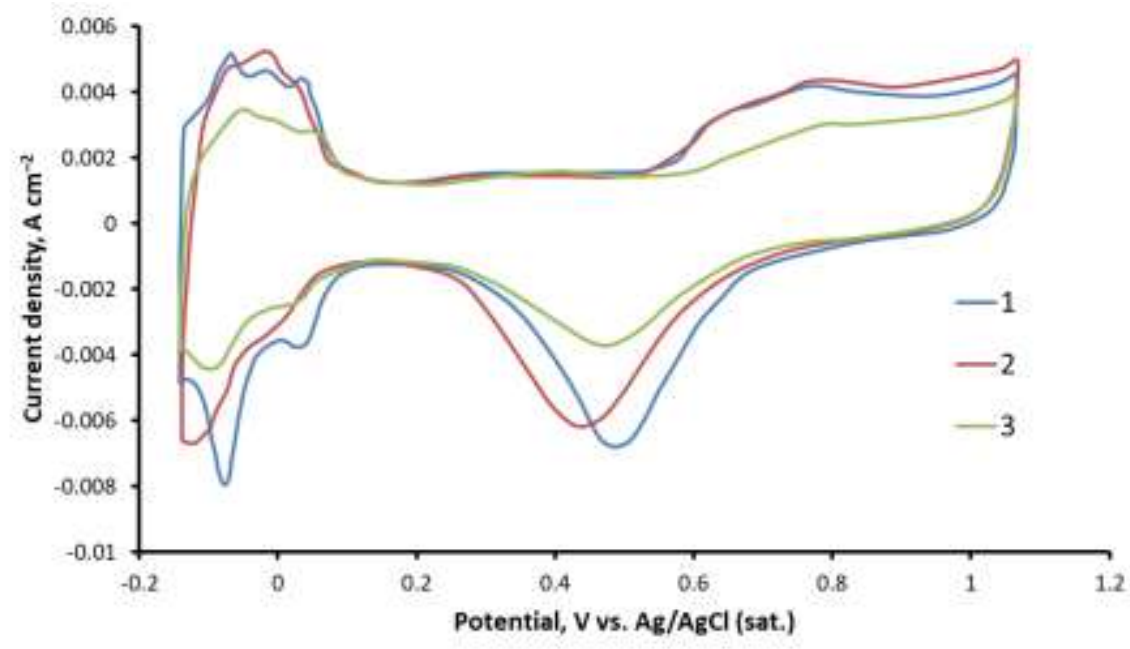

Fig. 3. Cyclic voltammetry curves of electrocatalysts: (1) $\mathrm{Pt}^{20} / \mathrm{CNF}$, (2) $\mathrm{Pt}^{20} /$ Vulcan XC-72R and (3) $\mathrm{Pt}^{20} / \mathrm{CNF}$ (MIS).

Electrocatalysts activity in oxygen density of $\mathrm{Pt}^{40} / \mathrm{MWCNTs}, \mathrm{Pt}^{40} /$ Vulcan XCevolution reaction (OER) could be compared through the quasi-stationary polarization curves. According to the fig. $4 \mathrm{~A}$ the current 72R, $\mathrm{Pt}^{40} / \mathrm{RGO}$ and $\mathrm{Pt}^{20} / \mathrm{CNF}$ (MIS) at $1.25 \mathrm{~V}$ (vs. SSCE(sat.)) is ca. 0.6, 0.46, 0.64 and 0.69 $\mathrm{A} \mathrm{g}^{-1} \mathrm{Pt}$, respectively, and the Tafel slope is ca. 
226.1, 299.7, 212.5 and $190.8 \mathrm{mV} \mathrm{dec.}^{-1}$,

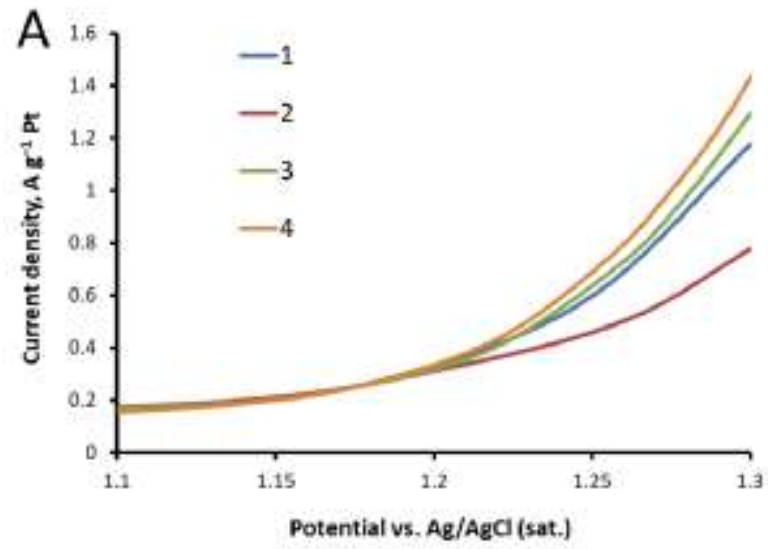

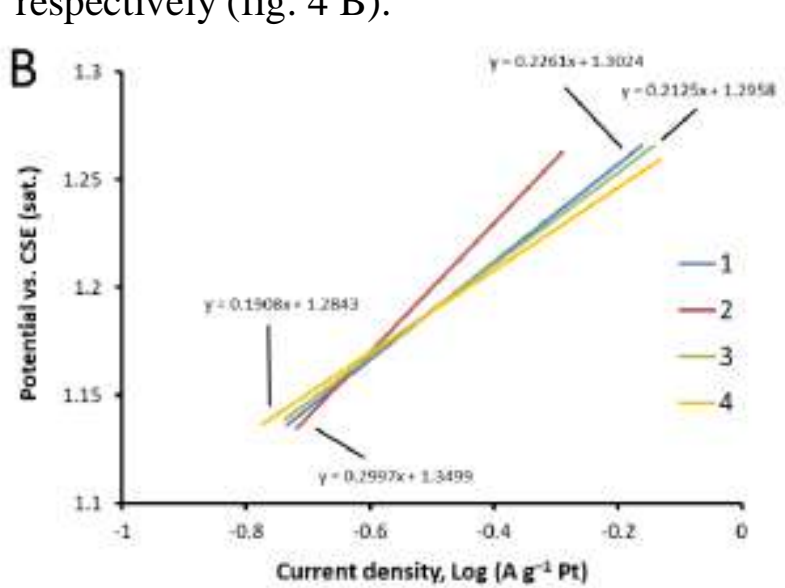

Fig. 4. Quasi-stationary polarization curves (A) and Tafel curves (B) of (1) $\mathrm{Pt}^{40} / \mathrm{MWCNTs}$; (2) $\mathrm{Pt}^{40} /$ Vulcan XC-72R; (3) $\mathrm{Pt}^{40} / \mathrm{RGO}$ and (4) $\mathrm{Pt}^{20} / \mathrm{CNF}$ (MIS) at anodic potentials.

Obtained current densities indicate low OER rate which is typical for Pt-based catalysts [26]. Significantly lower Tafel slope of $\mathrm{Pt}^{40} /$ Vulcan XC-72R could be described by strong oxidation of the carbon support under high anodic potential in the presence of $\mathrm{Pt}$ [27]. This effect is less pronounced in the case of catalysts supported on the MWCNTs and RGO due their high stability [25].

The OER Tafel slope of the $\mathrm{Pt}^{20} / \mathrm{CNF}$ (MIS) catalyst is ca. $190.8 \mathrm{mV} \mathrm{dec} .^{-1}$ which is significantly higher than the one of catalysts synthesized by chemical reduction approach. It could be related to the stronger interaction of $\mathrm{Pt}$ nanoparticles with the support due to the its intercalation into the carbon support [28]. Thus, instead of the lower EASA the activity of the catalysts prepared by the MIS approach is particularly same as the activity of chemically prepared catalysts. Due to the possible support particles agglomeration during the synthesis and electrode coating the MIS approach provide the preferred deposition of $\mathrm{Pt}$ particles on the outer agglomerate surface which provides the better access for the electrochemical reaction.

The quasi-stationary polarization curves of $\mathrm{Pt}^{40} / \mathrm{MWCNTs}$, $\mathrm{Pt}^{40} /$ Vulcan XC$72 \mathrm{R}, \mathrm{Pt}^{40} / \mathrm{RGO}$ and $\mathrm{Pt}^{20} / \mathrm{CNF}$ (MIS) are shown on fig. 5 .
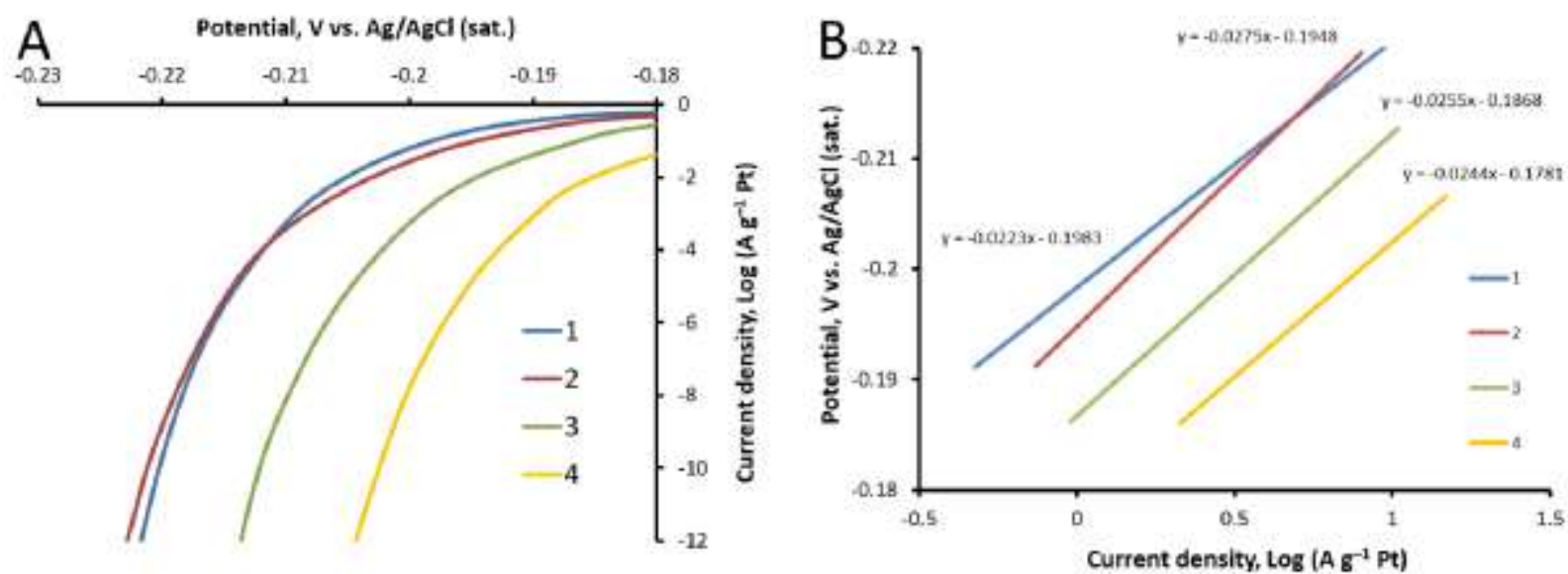

Fig. 5. Quasi-stationary polarization curves (A) and Tafel curves (B) of (1) $\mathrm{Pt}^{40} / \mathrm{MWCNTs}$, (2) $\mathrm{Pt}^{40} /$ Vulcan XC-72R, (3) $\mathrm{Pt}^{40} / \mathrm{RGO}$ and (4) $\mathrm{Pt}^{20} / \mathrm{CNF}$ (MIS) at cathodic potentials.

The specific activity of the evolution reaction (HER) is 1.22, 1.58, 3.24 $\mathrm{Pt}^{40}$ /MWCNTs, $\quad \mathrm{Pt}^{40} /$ Vulcan $\mathrm{XC}-72 \mathrm{R}, \quad$ and $7.81 \mathrm{~A} \mathrm{~g}^{-1} \mathrm{Pt}$, respectively (fig. $5 \mathrm{~A}$ ). The $\mathrm{Pt}^{40} / \mathrm{RGO}$ and $\mathrm{Pt}^{20} / \mathrm{CNF}$ (MIS) in hydrogen Tafel slope of $\mathrm{Pt}^{40} / \mathrm{MWCNTs}$, $\mathrm{Pt}^{40} /$ Vulcan 
$\mathrm{XC}-72 \mathrm{R}, \mathrm{Pt}^{40} / \mathrm{RGO}$ and $\mathrm{Pt}^{20} / \mathrm{CNF}$ (MIS) is ca.

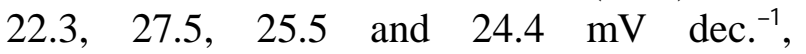
respectively (fig. 5 B). These Tafel slope values are quite similar and slightly lower than typical for $\mathrm{Pt} / \mathrm{C}$ electrocatalysts $(30-40 \mathrm{mV}$ dec. $^{-1}$ when the limiting reaction step is Tafel step or Heyrovsky step, respectively [29]). The reason of the obtained Tafel slopes may be the specific interaction of $\mathrm{Pt}$ nanoparticles with carbon support. $\mathrm{Pt}^{40} / \mathrm{RGO}$ and $\mathrm{Pt}^{20} / \mathrm{CNF}$ (MIS) demonstrate higher HER activity due to the higher EASA and Pt-carbon support interaction. Moreover, the high activity of $\mathrm{Pt}^{20} / \mathrm{CNF}$ (MIS) could be related to the preferred location of Pt nanoparticles over the outer support particles agglomerates surface.

\subsection{PEMFC testing}

The performance of PEMFC catalytic layers depends not only on the EASA of Pt nanoparticles and their specific activity, but also on the catalytic layer structure, which affects the layer conductivity (both ionic and electronic) and the layer permeability to reagents and reaction products [18].

The performance of PEMFC with MEAs based on various cathode electrocatalysts are shown in Fig. 6. The current density of the MEA equipped with $\mathrm{Pt}^{40} / \mathrm{MWCNTs}, \quad \mathrm{Pt}^{40} /$ Vulcan XC-72R, $\mathrm{Pt}^{40} / \mathrm{RGO}$ and $\mathrm{Pt}^{20} / \mathrm{CNF}$ (MIS) cathode catalysts at voltage of $0.7 \mathrm{~V}$ is ca. $1.02,1.1$, 1.12 and $0.925 \mathrm{~A} \mathrm{~cm}^{-2}$, respectively, and maximum output power density is ca. 0.84, $0.88,0.91$ and $0.75 \mathrm{~W} \mathrm{~cm}^{-2}$, respectively. The MEA performance with the cathode catalytic layer based on $\mathrm{Pt}^{20} / \mathrm{CNF}$ (MIS) is lower in comparison with other MEAs and, therefore, its maximum power density is $12-20 \%$ lower even at a similar cathode $\mathrm{Pt}$ loading. This result could be ascribed to the fact that at the same Pt loading the layer thickness is higher when the catalyst $\mathrm{Pt}$ percentage is lower, which leads to increasing mass transfer losses as well as to decreasing of its proton and electron conductivity [30].

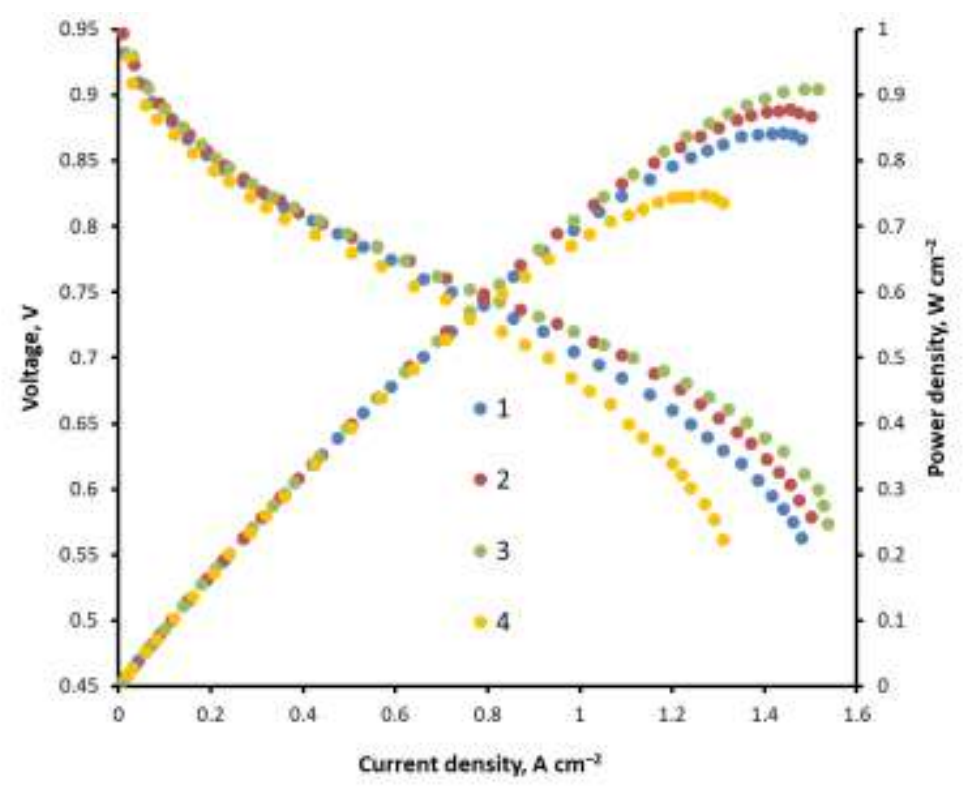

Fig. 6. The performance of the PEMFC with different cathode catalysts: (1) $\mathrm{Pt}^{40} /$ MWCNTs, (2) $\mathrm{Pt}^{40} /$ Vulcan XC-72R, (3) $\mathrm{Pt}^{40} / \mathrm{RGO}$ и (4) $\mathrm{Pt}^{20} / \mathrm{CNF}$ (MIS). The anode catalyst is $\mathrm{Pt}^{40} / \mathrm{Vulcan} \mathrm{XC}-72 \mathrm{R}$. The $\mathrm{Pt}$ loading on the cathode and anode is $0.4 \mathrm{mg} \mathrm{cm}^{-1}$ and $0.2 \mathrm{mg} \mathrm{cm}^{-}$ ${ }^{1}$, respectively. The pressure of $\mathrm{H}_{2}$ and $\mathrm{O}_{2}$ is 1 bar. The gas relative humidity is $100 \%$. The working temperature is $60^{\circ} \mathrm{C}$.

The result for MEA based on $\mathrm{Pt}^{40}$ /MWCNTs, $\mathrm{Pt}^{40} /$ Vulcan $\mathrm{XC}-72 \mathrm{R}$ and $\mathrm{Pt}^{40} / \mathrm{RGO}$ is in good agreement with the catalysts EASA values (Table 1). However, the performance of the MEA based on the magnetron-ion sputtered catalyst is higher than expected considering its low EASA value. It is consistent with the hypothesis made above that 
the Pt nanoparticles of the MIS prepared catalyst are better accessed for electrochemical process.

\section{Conclusions}

Carbon supports described in presented work (MWCNT, carbon black Vulcan XC-72R and $\mathrm{CNF}$ ) have quite close values of characteristic dimension of ca. 20-60 nm and BET specific surface are of ca. $130-230 \mathrm{~m}^{2} \mathrm{~g}^{-}$ 1. Primary support particles forms agglomerates. Pt nanoparticles located on the outer surface of support agglomerates mainly take part in electrochemical reactions. RGO is a flake structured material (agglomerated sheets) with high aspect ratio (length-tothickness ratio) and thus its characteristic dimension should be taken equal to 100-200 nm. The chemical reduction synthesis approach allows to obtain electrocatalysts with better Pt nanoparticles dispersion and higher
EASA. From the other hand the mass specific activity of $\mathrm{Pt}^{20} / \mathrm{CNF}$ (MIS) in OER is higher than the one of $\mathrm{Pt}^{40} / \mathrm{MWCNTs}, \mathrm{Pt}^{40} /$ Vulcan $\mathrm{XC}-72 \mathrm{R}, \mathrm{Pt}^{40} / \mathrm{RGO}$. The capability of covering mainly the outer surface of carbon support agglomerates with Pt nanoparticles when the MIS approach used is suggested. This approach allows to increase the noble metal utilization which confirms by studies in both liquid electrolyte media and PEMFC. The higher stability of catalysts supported on MWCNT, CNF and RGO at high anode polarization is demonstrated as well. Further study and optimization of magnetron-ion sputtering of metals over the carbon support powders is necessary.

\section{Acknowledgements}

This research was conducted with financial support of the Ministry of Science and Higher Education of the Russian Federation (unique project identifier RFMEFI60417X0171) in National Research Center "Kurchatov Institute", Russia.

\section{References}

$\begin{array}{cccc}\text { 1. Grigoriev } & \text { S.A., } & \text { Pushkarev } & \text { A.S., } \\ \text { Kalinichenko } & \text { V.N., } & \text { Pushkareva } & \text { I.V., }\end{array}$ Presnyakov M.Yu., Fateev V.N. Electrocatalytic Layers Based on Reduced Graphene Oxide for Fabrication of LowTemperature Fuel Cells. Kinetic and Catalysis. 2015, vol. 56, no. 5, pp. 689693.

2. Kalinnikov A.A., Ostrovskii S.V., Porembskii V.I., Pushkarev A.S., Fateev V.N. Study of the Electrochemical Oxygen Pump Based on Solid Polymer Electrolyte. Russ. J. Appl. Chem. 2018, vol. 91, pp. 927-929.

3. Akelkina S.V., Pushkarev A.S., Grigoriev S.A., Pushkareva I.V., Fateev V.N. Anode with the Active Layer for Electrosynthesizing Ozone in a System with Solid Polymer Electrolyte. Russ. J. Electrochem. 2018, vol. 54, pp. 251-257.

4. Kulova T.L., Nikolaev I.I., Fateev V.N., Aliyev A.Sh. Electrochemical systems of energy accumulation. Chemical Problems.
2018, no. 1, pp. 9-34.

5. Pushkarev A.S., Pushkareva I.V., Du Preez S.P., Ivanova N.A., Grigoriev S.A., Slavcheva E.P., Bessarabov D.G., Fateev V.N., Aliyev A.Sh. Iridium catalyst supported on conductive titanium oxides for polymer electrolyte membrane electrolysis. Chemical Problems. 2019, no. 1 (17), pp. 9-15.

6. Xu Z., Zhang H., Zhong H., Lu Q., Wang Y., Su D. Effect of particle size on the activity and durability of the $\mathrm{Pt} / \mathrm{C}$ electrocatalyst for proton exchange membrane fuel cells. Appl. Catal. B: Environ. 2012, vol. 111-112, pp. 264-270.

7. Alexeeva O.K., Fateev V.N. Application of the magnetron sputtering for nanostructured electrocatalysts synthesis. Int. J. Hydrogen Energy. 2016, vol. 41, pp. 3373-3386.

8. Grigoriev S.A., Lyutikova, E.K., Pritulenko, E.G., Samsonov, D.P., Fateev, V.N. Synthesis and test of palladium-based nanostructured anodic electrocatalysts for 
hydrogen fuel cells with solid polymer electrolyte. Russ. J. Electrochem. 2006, vol. 42, pp. 1251-1254.

9. Sung C. C., Liu C. Y., Colin C. J. Durability improvement at high current density by graphene networks on PEM fuel cell. Int. $J$. Hydrogen Energy. 2014, vol. 39, pp. 11706-11712.

10. Sehkyu P., Yuyan S., Haiying, W., Peter C. Rieke, V. Viswanathan V., Silas A. Towne, Saraf L.V. Design of graphene sheets-supported Pt catalyst layer in PEM fuel cells. Electrochem. Commun. 2011, vol. 13, pp. 258-261.

11. Sui S., Wang X., Zhou X., Su Y., Riffat S., Liu C. A comprehensive review of $\mathrm{Pt}$ electrocatalysts for the oxygen reduction reaction: Nanostructure, activity, mechanism and carbon support in PEM fuel cells. J. Mater. Chem. A. 2017, vol. 5, pp. 1808-1825.

12. Passalacqua E., Lufrano F., Squadrio G., Patti A., Giorgi L. Nafion content in the catalyst layer of polymer electrolyte fuel cells: effects on structure and performance. Electrohim. Acta. 2001, vol. 46, pp. 799805.

13. Podyacheva O.Yu., Shmakova A.N, Boronina A.I., Kibis L.S., Koscheeva S.V., Gerasimova E. Yu, Ismagilova Z.R. A correlation between structural changes in a $\mathrm{Ni}-\mathrm{Cu}$ catalyst during decomposition of ethylene/ammonia mixture and properties of nitrogen-doped carbon nanofibers. $J$. Energ. Chem. 2013, vol. 22, pp. 270-278.

14. Baranov I.E., Nikolaev I.I., Pushkarev A.S., Pushkareva I.V., Kalinnikov A.A., Fateev V.N. Numerical Modelling of Polymer Electrolyte Fuel Cell Catalyst Layer with Different Carbon Supports. Int. J. Electrochem. Sci. 2018, vol. 13, pp. 8673-8685.

15. Hummers W.S., Offman R.E. Preparation of Graphitic Oxide. J. Amer. Chem. Soc. 1958, vol. 80, pp. 1339.

16. Pushkarev A.S., Pushkareva I.V., Grigoriev S.A., Kalinichenko V.N., Presniakov M.Yu., Fateev V.N. Electrocatalytic layers modified by reduced graphene oxide for PEM fuel cells. Int. J.
Hydrogen Energy. 2015, vol. 40, pp. 14492-14497.

17. Alekseeva O.K., Lutikova E.K., Markelov V.V., Porembsky V.I., Fateev V.N. Stationary and Pulsed Magnetron Sputtering Technologies for Protective/Catalyst Layer Production for PEM Systems. Int. J. Electrochem. Sci. 2018, vol. 13, pp. 797-811.

18. Grigoriev S.A, Fateev V.N, Lutikova E.K., Grigoriev A.S, Bessarabov D.G., Wei X., $\mathrm{Ge} \quad$ J. CNF-supported Platinum Electrocatalysts Synthesized Using PlasmaAssisted Sputtering in Pulse Conditions for the Application in a High-Temperature PEM Fuel Cell. Int. J. Electrochem. Sci. 2016, vol. 11, pp. 2085-2096.

19. Grigoriev S.A., Millet P., Porembsky V.I., Fateev, V.N. Development and preliminary testing of a unitized regenerative fuel cell based on PEM technology. Int. J. Hydrogen Energy. 2011, vol. 36, pp. 4164-4168.

20. He D., Jiang Y., Lv H., Pan M., Mu S. Nitrogen-doped reduced graphene oxide supports for noble metal catalysts with greatly enhanced activity and stability. Appl. Catal. B: Environ. 2013, vol. 132133, pp. 379-388.

21. Yu X., Ye S. Recent advances in activity and durability enhancement of $\mathrm{Pt} / \mathrm{C}$ catalytic cathode in PEMFC: Part II: Degradation mechanism and durability enhancement of carbon supported platinum catalyst. J. Power Sources. 2007, vol. 172, pp. 145-154.

22. Antolini. E. Graphene as a new carbon support for low-temperature fuel cell catalysts. Appl. Catal. B Environ. 2012, vol. 123-124, pp. 52-68.

23. Grigoriev S.A., Fateev V.N., Pushkarev A.S., Pushkareva I.V., Ivanova N.A., Kalinichenko V.N., Presnyakov M.Yu., Wei X. Reduced Graphene Oxide and Its Modifications as Catalyst Supports and Catalyst Layer Modifiers for PEMFC. Materials. 2018, vol. 11, pp. 1405.

24. He D., Cheng K., Peng T., Sun X., Pan M., $\mathrm{Mu}$ S. Bifunctional effect of reduced graphene oxides to support active metal nanoparticles for oxygen reduction reaction 
and stability. J. Mater. Chem. 2012, vol. 22, pp. 21298-21304.

25. Antolini E. Carbon supports for lowtemperature fuel cell catalysts. Appl. Catal. B Environ. 2009, vol. 88, pp. 1-24.

26. Reier, T., Oezaslan, M., Strasser, P. Electrocatalytic Oxygen Evolution Reaction (OER) on Ru, Ir, and Pt Catalysts: A Comparative Study of Nanoparticles and Bulk Materials. ACS Catal. 2012, vol. 2, pp. 1765-1772.

27. Meier J.C., Katsounaros I., Galeano C., Bongard H. J., Topalov A.A., Kostka A., Karschin A., Schuth F., Mayrhofer K. J. J. Stability investigations of electrocatalysts on the nanoscale. Energy Environ. Sci. 2012, vol. 5, pp. 9319-9330.
28. Calvillo L., Gangeri M., Perathoner S., Centi G., Moliner R., Lázaro M.J. Effect of the support properties on the preparation and performance of platinum catalysts supported on carbon nanofibers. J. Power Sources. 2009, vol. 192, pp. 144-150.

29. Shinagawa T., Garcia-Esparza A.T., Takanabe K. Insight on Tafel slopes from a microkinetic analysis of aqueous electrocatalysis for energyconversion. Sci. Rep. 2015, vol. 5, pp. 13801.

30. Antolini E. Structural parameters of supported fuel cell catalysts: The effect of particle size, inter-particle distance and metal loading on catalytic activity and fuel cell performance. Appl. Catal. B: Environ. 2016, vol. 181, pp. 298-313.

\title{
СРАВНИТЕЛЬНОЕ ИССЛЕДОВАНИЕ ПЛАТИНОВЫХ КАТАЛИЗАТОРОВ НА РАЗЛИЧНЫХ УГЛЕРОДНЫХ НОСИТЕЛЯХ ДЛЯ ТВЕРДОПОЛИМЕРНЫХ ЭЛЕКТРОХИМИЧЕСКИХ СИСТЕМ
}

\author{
И.Е. Баранов ${ }^{1}$ В.И. Порембский ${ }^{1}$, Е.К. Лютикова ${ }^{1}$, И.И. Николаев ${ }^{I}$, В.В. Маркелов ${ }^{1}$, \\ О.К. Алексеева ${ }^{1}$, С.В. Островский ${ }^{1}$, А.А. Калинников ${ }^{1}$ С.В. Акелькина, \\ А.С. Пуикарев ${ }^{1,2}$, М.А. Соловьев ${ }^{1,2}$, И.В. Пуикарева ${ }^{1,2}$, В.Н. Фатеев \\ ${ }^{1}$ Национальный исследовательский центр «Курчатовский институт», \\ Москва, пл. Академика Курчатова, д. 1, 123182, Россия, e-mail: fateev_vn@nrcki.ru \\ ${ }^{2}$ Национальный исследовательский университет «МЭИ» \\ Москва, ул. Красноказарменная, д. 14, 111250, Россия
}

\begin{abstract}
Представлены результаты сравнительного исследования электрокатализаторов для электрохимических систем с твердым полимерным электролитом, синтезированные методами химического восстановления и импульсного магнетронно-ионного распьления. В качестве носителей наночастии Pt использовались различные углеродные наноматериалы: углеродная сажа, нанотрубки, нановолокна и восстановленный оксид графена. Проведены электрохимические исследования полученных электрокатализаторов $u$ их тестирование в составе мембранно-электродного блока топливного элемента. Изучено влияние морфологии носителя и метода нанесения наночастии $P t$ на электрохимически активную поверхность электрокатализатора, а также перспективность применения метода магнетронно-ионного распыления для синтеза электрокатализаторов.
\end{abstract}

Ключевые слова: катализатор на носителе; восстановленный оксид графена, углеродные нановолокна; магнетронно-ионное напыление; топливный элемент $c$ твердым полимерным электролитом.

\section{BORK POLIMERLİ ELEKTROKIMYOVI SISTEMLOR ÜÇÜN MÜXTOLIFF KARBON DAŞIYICILAR ÜZORINDӘ Pt KATALIZATORLARIN MÜQAYISOLI TODQIQQI}

\author{
I.E. Baranov ${ }^{1}$, V.I. Porebski ${ }^{1}$, E.K. Lyutikova ${ }^{1}$, I.I. Nikolaev ${ }^{I}$, V.V. Markelov ${ }^{1}$, O.K. \\ Alekseyeva $^{I}$, S.V. Ostrovski ${ }^{1}$, A.A. Kalinnikov ${ }^{1}$, S.V. Akelkina ${ }^{I}$, A.S. Puşkarev ${ }^{1,2}$, \\ M.A. Soloviev ${ }^{1.2}$, I.V. Puşkareva ${ }^{1.2}$, V.N. Fateyev ${ }^{I}$
}


"Kurçatov Institutu" Milli tədqiqat markazi ${ }^{l}$

123182, Moskva, Akadimik Kurçatov meydanı,1

e-mail:fateev_vn@nrcki.ru

"MEI" Milli tadqiqat universiteti ${ }^{2}$

111250, Moskva, Krasnokazarmennaya küç, 14

Maqaladə bərk polimerli elektrokimyəvi sistemlar üçün kimyəvi reduksiya va maqnetron-ion sapilma metodları ila sintez olunmuş elektrokatalizatorların tadqiqinin naticalari verilib. Pt nanohissaciklari üçün daşıyıcı kimi müxtəlif karbon nanomateriallar istifado olunub: duda, nanoborular, nanoliflar, reduksiya olunmuş qrafen oksidi. Alınan elektrokatalizatorlar yanacaq elementinin membran-elektrod blokunun torkibindo yoxlanılıb. Daşıyıcının morfologiyasının vo Pt nanohissaciklarinin çökdürma metodlarınının elektrokatalizatorun aktiv sathina tasiri va elektrokatalizatorların sintezindo maqnetron-ion sapilma metodunun tətbiqinin perspektivliyi öyranilib.

Açar sözlor: elektrokatalizator, qrafen oksidi, nanoborular, nanoliflar, maqnetron-ion səpilma metodu, bark polimerli elektrolitli yanacaq elementi 